\title{
THE ACROSOME OF THE HUMAN SPERMATOZOON: A NEW METHOD FOR ITS EXTRACTION, AND AN ANALYSIS OF ITS TRYPSIN-LIKE ENZYME ACTIVITY
}

\author{
H. PEDERSEN* \\ Department of Anatomy, and \\ Laboratories of Human Reproduction and Reproductive Biology, \\ Harvard Medical School, Boston, Massachusetts 02115, U.S.A. \\ (Received 1st September 1971, accepted 24th Fanuary 1972)
}

\begin{abstract}
Summary. A method is described for isolating the acrosomal material from human spermatozoa. Ejaculated spermatozoa are washed in a balanced salt solution containing glucose and dextran and are then rapidly frozen in liquid nitrogen, thawed at room temperature and the supernatant is collected after centrifugation. Electron microscope observations on the sperm pellet indicate a fairly selective removal of the acrosomal content with only minor damage to other parts of the spermatozoon.

The presence of trypsin-like enzyme activity in the supernatant material thus obtained, was demonstrated by its ability to digest BAEE and TAME and by inhibition of this activity with soybean trypsin inhibitor and TLCK. Blood serum and seminal plasma were both found to contain a potent inhibitor of this enzyme activity. A reasonably consistent activity per mg of 'acrosomal protein' makes it improbable that the enzymatic activity is found in an inhibited state in ejaculated spermatozoa.
\end{abstract}

\section{INTRODUCTION}

Several attempts have been made to remove the acrosomal cap from the spermatozoon for biochemical study. Clermont, Clegg \& Leblond (1955) used $0 \cdot 1 \mathrm{~N}-\mathrm{NaOH}$ to remove the acrosome of guinea-pig spermatozoa, success being judged by the disappearance of periodic acid-Schiff stainable material from the acrosome region. With ram and bull spermatozoa, $0.0125 \mathrm{~N}-\mathrm{NaOH}$ is effective as is also the surface-active substance, cetyl-trimethylammonium bromide (Hathaway \& Hartree, 1963). The use of the detergent, Hyamine, introduced by Hartree \& Srivastava (1965), has been widely accepted as a method for accomplishing a rather selective removal of the acrosome of spermatozoa from several species (Hartree \& Srivastava, 1965; Stambaugh \& Buckley, 1969; Zaneveld, Srivastava \& Williams, 1969; Allison \& Hartree, 1970). Other methods recommended include the use of a colloid mill (Morton, 1968),

\footnotetext{
* Present address: Laboratory of Reproductive Biology, Department of Obstetrics and Gynecology, Rigshospitalet, 2100 Copenhagen $\emptyset$, Denmark.
} 
barbiturate and Triton X-100 (Teichman \& Bernstein, 1969) and sonication (Stambaugh \& Buckley, 1969). The material obtained by these methods is reported to contain a lipoglycoprotein complex, and enzyme assays have revealed the presence of a number of lysosomal enzymes including proteases (Teichman \& Bernstein, 1969; Allison \& Hartree, 1970), hyaluronidase (Stambaugh \& Buckley, 1969; Zaneveld \& Williams, 1970), trypsin-like enzyme activity (Stambaugh \& Buckley, 1969; Zaneveld et al., 1969), neuraminidase and a 'corona-penetrating enzyme' (Srivastava, Zaneveld \& Williams, 1970; Zaneveld \& Williams, 1970). The material extracted from acrosomes is said to dissolve the zona pellucida of rabbit eggs (Srivastava, Adams \& Hartree, 1965; Stambaugh \& Buckley, 1968a, 1969).

The development of a technique which will allow the selective removal of acrosomes from human spermatozoa is desirable for several reasons. Better understanding of the biochemistry of the acrosome might contribute to correction of infertility or to the development of new approaches to conception control. Antibodies against spermatozoa have been suggested as the basis for certain cases of human infertility (Franklin \& Dukes, 1964; Strauss, 1965; Schwimmer, Ustay \& Behrman, 1967; Flällbrant, 1968; Hjort \& Hansen, 1971; Otani, Ino, Inoue \& Kagkami, 1971), and some evidence points to the acrosome as the major site of the antigens involved. A means of selectively removing the acrosome might provide the first step toward characterization of those antigens.

\section{MATERIALS AND METHODS}

\section{Semen donors}

Seventeen ejaculates from nine healthy human donors, three of which were known to be fertile, were used in this study. The volume of the ejaculates ranged from 1.3 to $4.7 \mathrm{ml}$ after at least 2 days of sexual abstinence, and the ejaculates contained 72 to $142 \times 10^{6}$ cells $/ \mathrm{ml}$. Of these, 10 to $40 \%$ were immotile and 15 to $22 \%$ had abnormal head forms. Only ejaculates with a minimum of débris and contamination with cells other than spermatozoa were selected. Semen from each donor was processed for electron microscopy, and all the samples were found to be in accordance with previous electron microscopical studies of human spermatozoa (Pedersen, 1969, 1970a, b, 1972).

\section{Electron microscopy}

The semen was fixed for $15 \mathrm{~min}$ in about 2 vol of $4 \%$ collidine-buffered glutaraldehyde with $4 \%$ sucrose. The sample was then centrifuged for $15 \mathrm{~min}$ at $500 \mathrm{~g}$ in small plastic centrifuge tubes. The ends of these, containing a loose pellet, were then cut off and rinsed in collidine buffer, after which they were transferred to collidine-buffered $1.5 \%$ osmium tetroxide for $1 \mathrm{hr}$ of further fixation. During dehydration in graded concentrations of ethanol, the tissue was gently removed from the tube ends. After completion of the dehydration in propylene oxide, the pellet was embedded in Epon 812 (Luft, 1961). Silver to dark grey sections cut with a diamond knife were stained with uranyl acetate in methanol and then with lead citrate and examined in a Philips 200 electron microscope. 
Isolation of the acrosome

The following solution was used for washing the spermatozoa: $\mathrm{CaCl}_{2} 120 \mathrm{mg}$, $\mathrm{KCl} 300 \mathrm{mg}, \mathrm{NaHCO}_{3} 150 \mathrm{mg}$, NaCl $3000 \mathrm{mg}$, glucose $500 \mathrm{mg}$, dextran 1000 mg (Sigma ${ }^{*}$, type $200 \mathrm{C}, \mathrm{M} .204 .000$ ), $\mathrm{H}_{2} \mathrm{O}$ to $500 \mathrm{ml}$. The $\mathrm{pH}$ of this solution was about 8.0. After liquefaction of the semen at room temperature, it was diluted 1:2 with the washing solution and was allowed to stand for 2 to $5 \mathrm{~min}$. The sample was then centrifuged at $4^{\circ} \mathrm{C}$ for $5 \mathrm{~min}$ at $225 \mathrm{~g}$ and the pellet (I) was discarded (Text-fig. 1). The supernatant (I) was centrifuged at $500 \mathrm{~g}$ for $15 \mathrm{~min}$, and the resulting pellet (II) was resuspended in the same volume of cold washing solution with a Pasteur pipette and washed twice, centrifuging at $500 \mathrm{~g}$ for $15 \mathrm{~min}$ in the cold room. The final pellet (V) was dispersed in washing solution containing $10 \%$ glycerol and was allowed to stand for $5 \mathrm{~min}$. The sample was then rapidly frozen by immersion in liquid nitrogen for $5 \mathrm{~min}$.

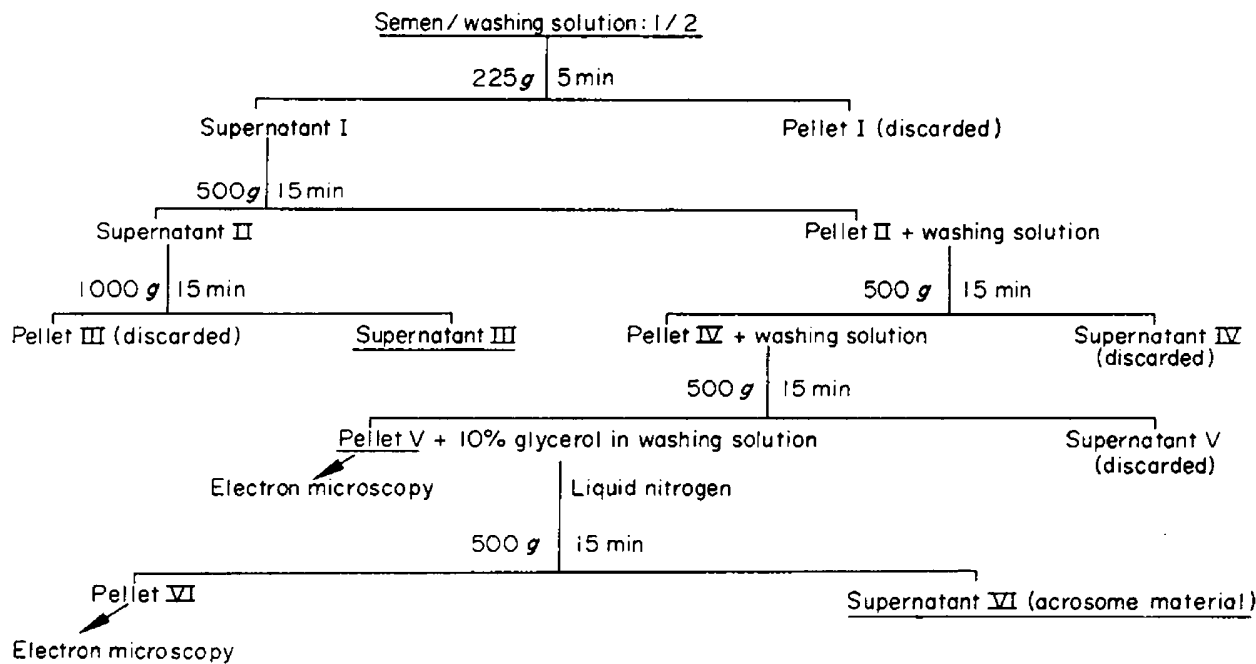

TEXT-FIG. 1. Schematic illustration of the procedure used for extraction of human acrosomal material.

After allowing it to thaw at room temperature, the sample was kept at $4^{\circ} \mathrm{C}$ for $15 \mathrm{~min}$ and then centrifuged for $15 \mathrm{~min}$ at $500 \mathrm{~g}$. The resultant supernatant (VI) was found to represent isolated acrosomal material. Supernatant (II) was centrifuged at $1000 \mathrm{~g}$ for $15 \mathrm{~min}$ in order to remove all cellular elements. The resulting supernatant (III), consisting of seminal plasma diluted $1: 2$ with washing solution, was kept for analysis. After washing, and after acrosome removal, some of the pellets were processed for electron microscopy to check the efficiency of the procedure.

\section{Analyses}

Protein concentrations were determined by the method of Lowry, Rosebrough, Farr \& Randall (1951). Spectrophotometric analyses of trypsin-like activity in the acrosomal preparation were performed with benzoylargininethyl ester (BAEE) (Bergmeyer, 1963) and with tosylargininmethyl ester (TAME) 
(Walsh, 1970) as substrates. Enzyme inhibition with soybean trypsin inhibitor and tosyllysinchloromethyl ketone (TLCK), seminal plasma and serum was assayed with TAME as a substrate.

\section{RESULTS}

The spermatozoa in the final pellet obtained after the washing procedure were fairly well preserved but most of them showed changes of varying degree in the acrosome and the overlying cell membrane. Characteristically, a loosened cell membrane covered a slightly to moderately thinned and swollen anterior acrosomal segment (Pl. 1, Figs. 1 and 2). The outer membrane of this segment was sometimes irregular and in acrosomes showing the most pronounced changes, there was a decreased density of the acrosomal contents. Accumulations of relatively dense, homogeneous material of similar texture could be seen in prominent outpocketings of the outer acrosomal membrane (Pl. I, Fig. 3). The pellet also contained some spermatids, a few leucocytes and varying amounts of other cellular elements.

The pellet obtained after the freezing and thawing and the subsequent centrifugation contained spermatozoa which were fairly well preserved except for an almost complete lack of acrosomes. In about $98 \%$ of the cells, the anterior segment of the acrosome was essentially absent, but often the inner acrosomal membrane persisted (Pl. 2, Figs. 4 to 6). In place of the acrosome, there were only loose membranes and vesicular elements scattered at irregular intervals around the anterior end of the head. In most of the cells, the equatorial segment was also extracted but, in about $20 \%$ of the cells, portions of this segment could still be recognized in varying degrees of preservation. The rest of the cell was not markedly affected by the procedure. In individual cells, however, some changes were found which varied in localization and extent. The postacrosomal sheath was affected to some degree (Pl. 2, Fig. 6), but usually its integrity was maintained (Pl. 3, Fig. 8). In the neck region and in the mid-piece, areas of rarefaction or dilution of cytoplasm were seen subjacent to a loosened cell membrane (Pl. 3, Fig. 7 and Pl. 4, Fig. 9). The cytoplasm of the neck region was partially lost in some cells though this area usually appeared fairly well preserved (Pl. 3, Fig. 7). Often, no change could be seen in the mitochondria but occasionally the matrix appeared to be somewhat thinned (Pl. 4, Fig. 9). The substructure of the axoneme was essentially unchanged throughout the length of the tail (Pl. 4, Figs. 9 to 11) and the substructure of the axonemal matrix (Pedersen, 1970) could easily be recognized. Often, the distal end of the tail would be hooked back upon itself or coiled up so that transverse sections showed two or more axonemes enclosed in the same cell membrane. This coiling was also observed in spermatozoa subjected only to the washing procedure. No deviations from the normal were observed in the chromatin nor in the appearance or extent of the nuclear vacuoles. Thus, from a morphological point of view, a fairly selective removal of the acrosomal contents was accomplished. This acrosomal material was subsequently analysed as described below.

The presence of trypsin-like enzyme activity was demonstrated by the ability of the acrosomal material in the supernate to digest BAEE and TAME at 

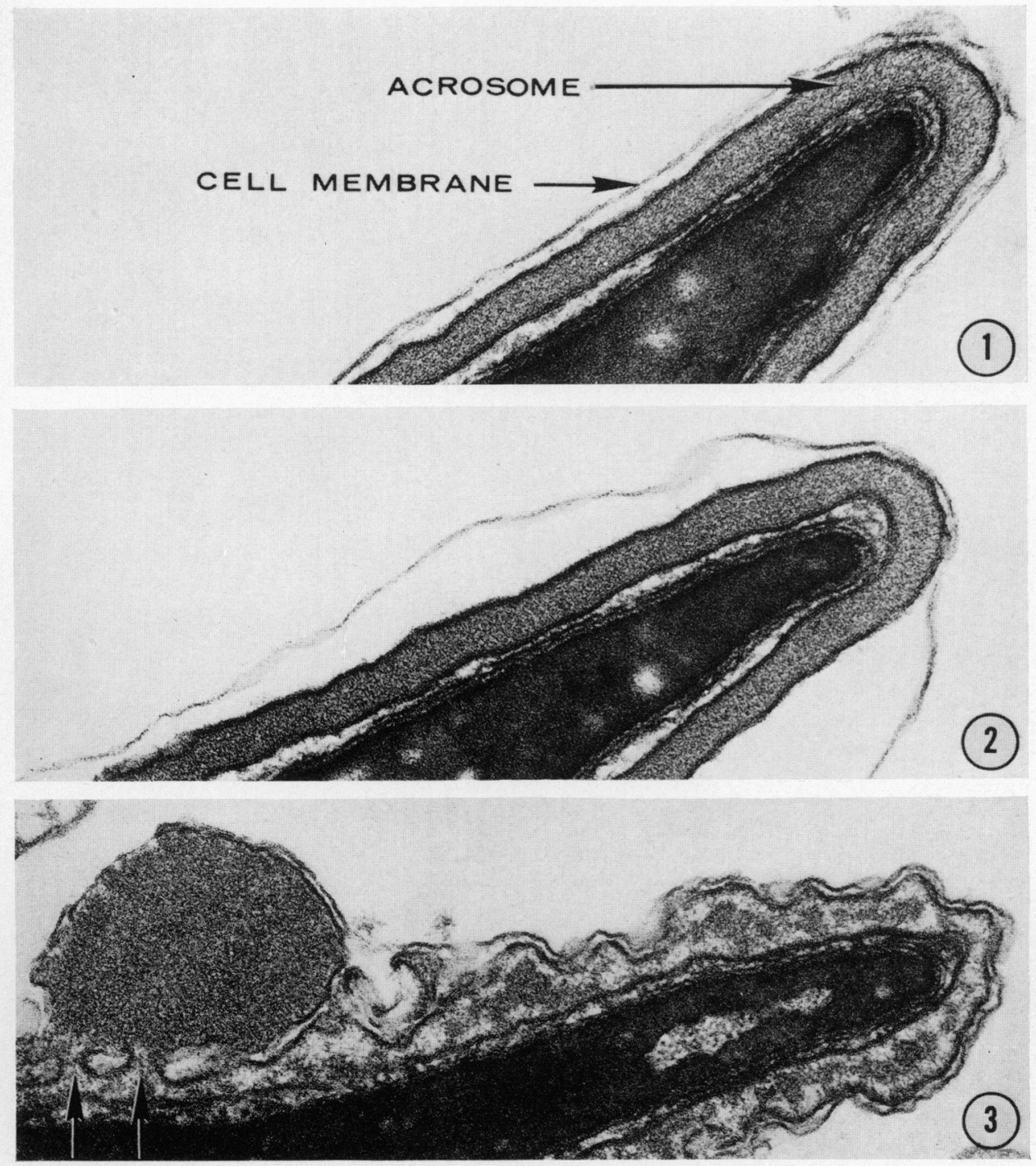

Fics. 1 10 3. These figures demonstrate progressive changes in the acrosome after the washing of human spermatozoa. In Fig. 1, the slightly thinned acrosome is covered by a closely apposed coll membrane. More often this membrane is loosened. as in Fig. 2. In some cells. the acrosome presents a less electron-dense appearance and has an irregular. cutline (Fig. 3). In such cells, localized accumulations of dense material are seen in outpocketings of the outer acrosome membrane (arrowed). 

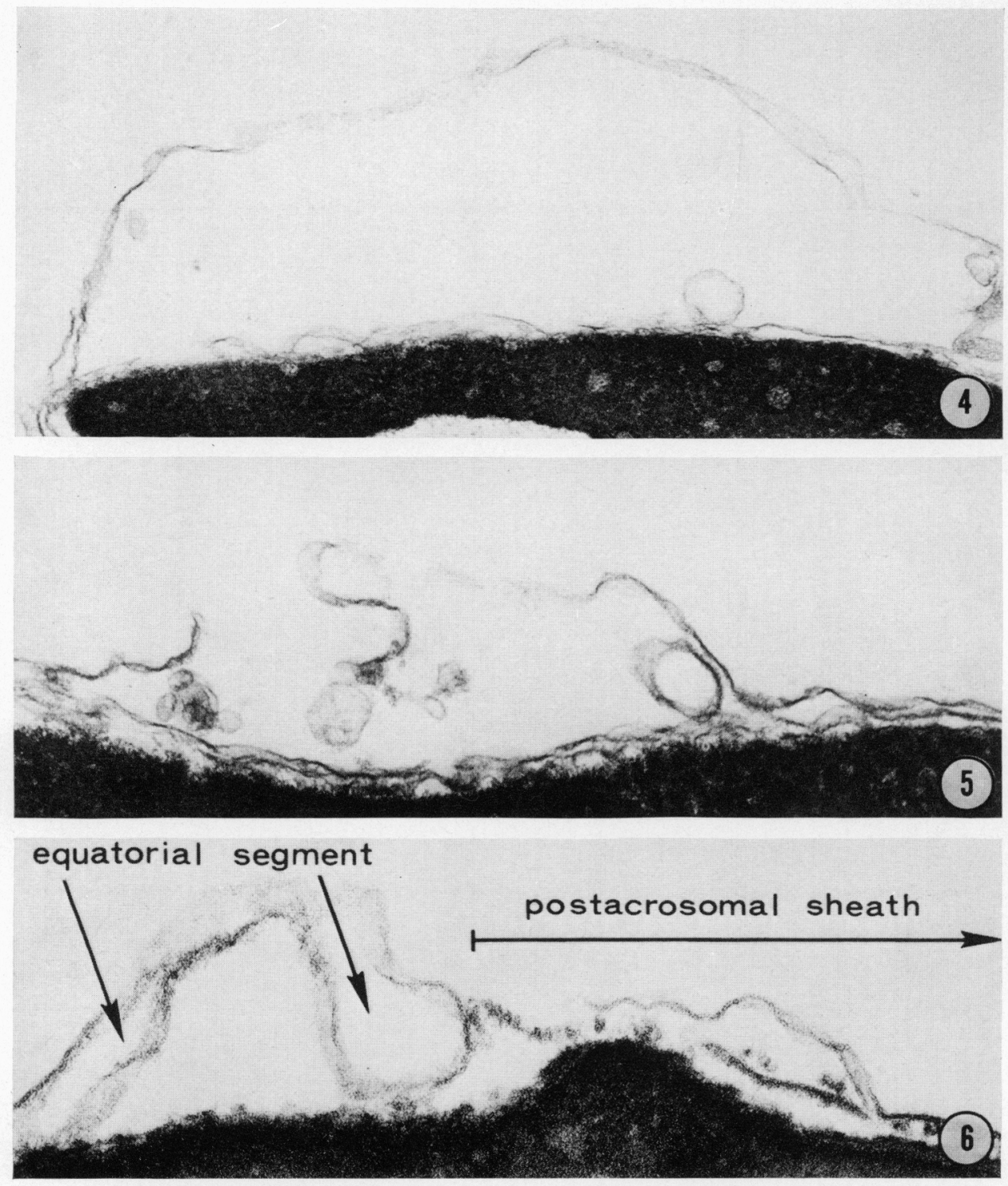

FIGs. 4 to 6 . The changes illustrated here are found after freezing and subsequent centrifugation. The content of the anterior segment of the acrosome is completely lost, only leaving loosened membranes and vesicular elements. In some cells, the inner acrosomal membrane is left but usually only partially. The equatorial segment is recognizable in about $20 \%$ of the cells, but usually there is appreciable thinning. The postacrosomal sheath is preserved to varying degrees. 
PLATE 3

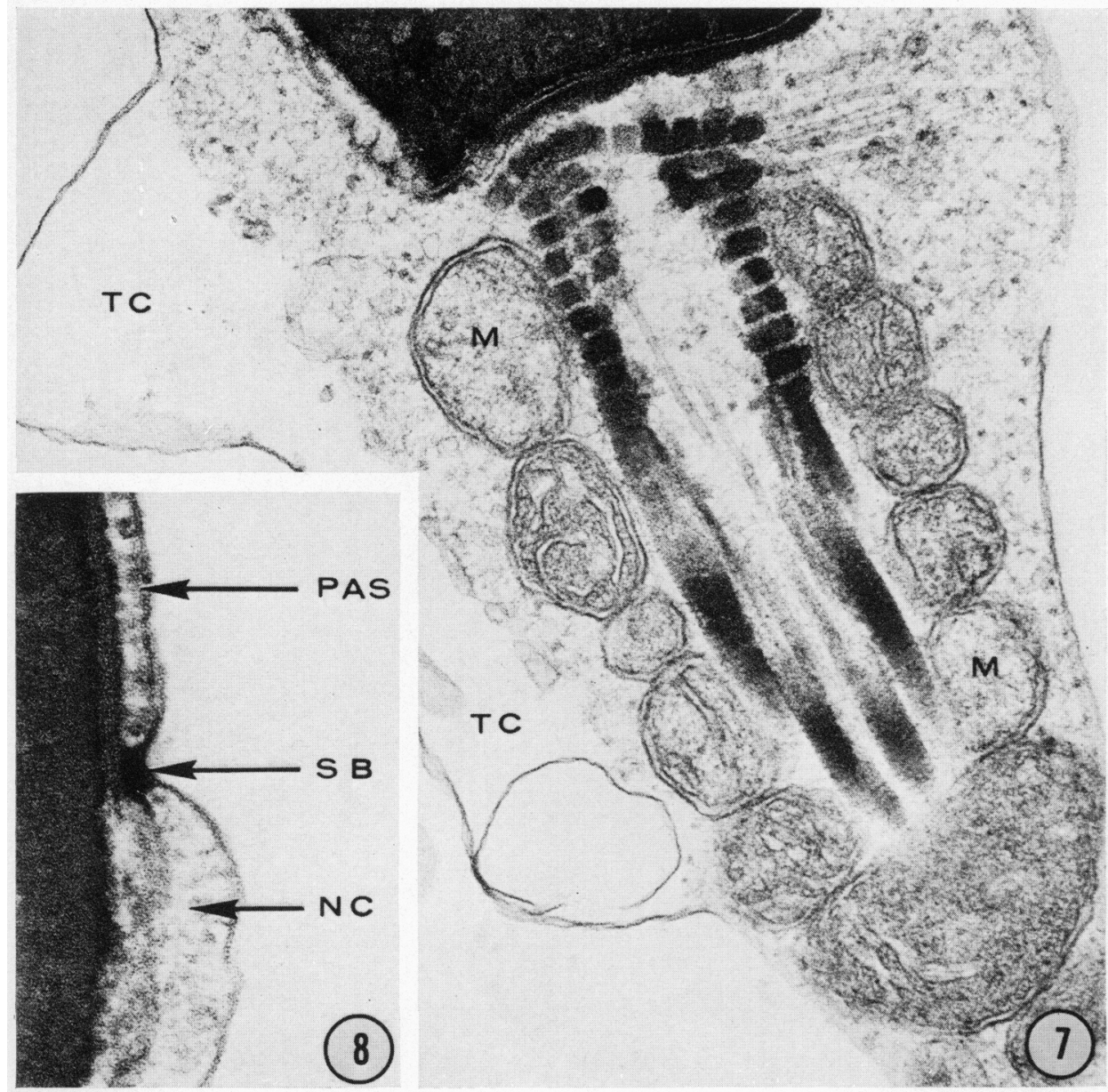

FIGs. 7 and 8 . The integrity of the neck region is usually well maintained after extraction of acrosomal material, though a thinned area subjacent to the cell membrane is often observed (TC). The mitochondrial substructure (M) is usually unaffected, but some thinning may occur. The striated band (SB) (Pedersen, 1972) which delineates a sharp boundary between the anterior extension of the neck cytoplasm (NG) and the postacrosomal sheath (PAS) is unchanged. 

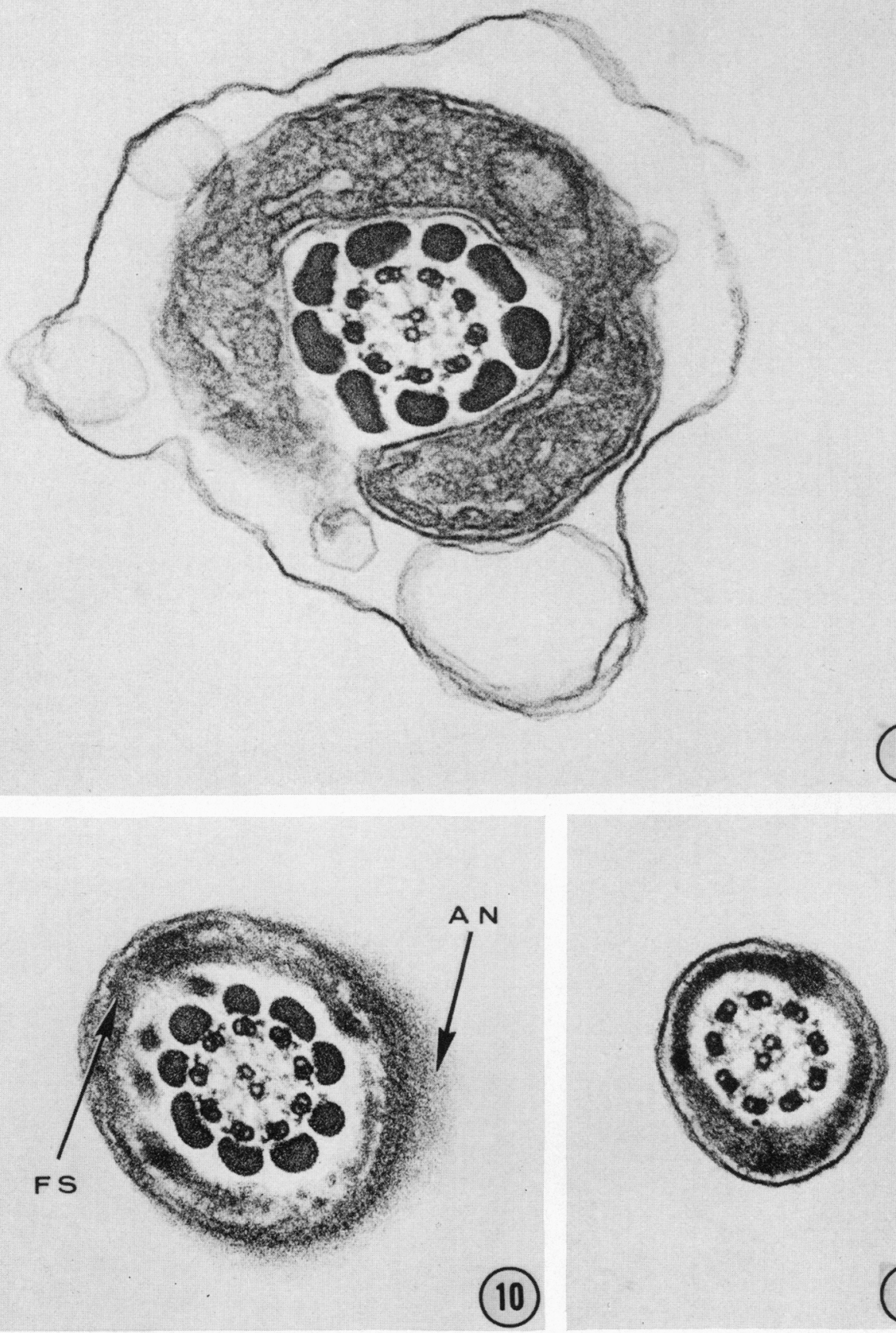

Figs. 9 to 11 . After extraction of acrosomal material, the substructure of the tail is usually well maintained. As in the neck region, a thinned area may be recognized subjacent to the cell membrane of the mid-piece (Fig. 9). The substructure of the axoneme, including the axonemal matrix, is largely unchanged. Figure 10 illustrates a section at the level of the transition between the annulus (AN) and the fibrous sheath (FS). 


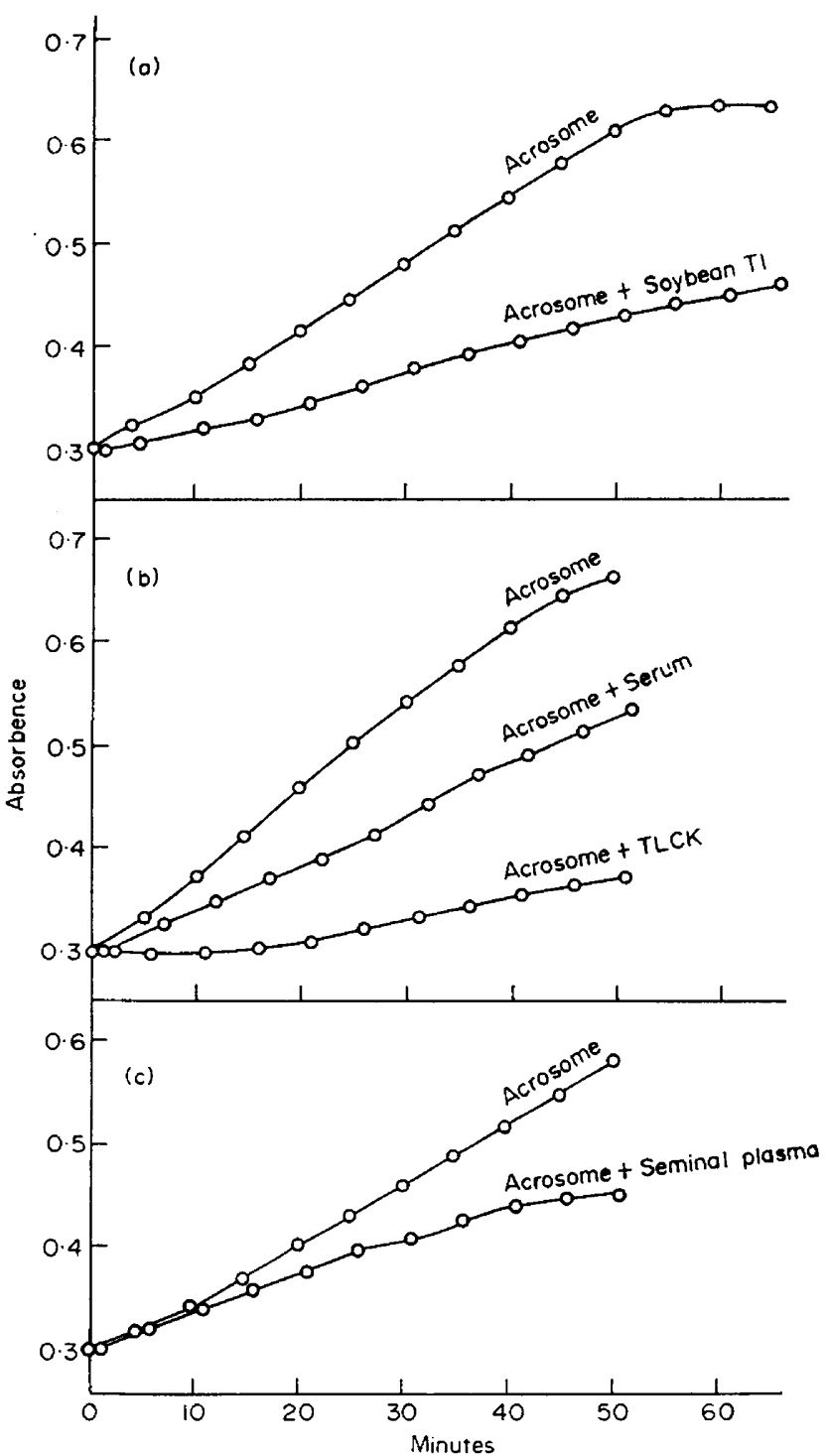

TEXT-FIG. 2. Curves based on spectrophotometric data. In each figure, the curves are transposed to a common starting point of absorbance to facilitate their comparison. In all cases, TAME was used as the substrate. Each cuvette contained $3 \mathrm{ml}$ of $1.04 \times 10^{-3} \mathrm{M}$ solution of TAME. (a) The control cuvette contained $0.15 \mathrm{ml}$ acrosomal extract with $0.05 \mathrm{ml}$ water; the other cuvette contained $0.15 \mathrm{ml}$ acrosomal extract with $0.05 \mathrm{ml}$ $0.03 \%$ soybean trypsin inhibitor. (b) These curves illustrate the inhibition of the human acrosomal preparation by serum and TLCK. The control cuvette contained $0.10 \mathrm{ml}$ acrosomal extract with $0.10 \mathrm{ml}$ water. The other two cuvettes contained $0.10 \mathrm{ml}$ acrosomal extract with $0.10 \mathrm{ml} 0.05 \%$ TLCK, and $0.10 \mathrm{ml}$ acrosomal extract with $0.05 \mathrm{ml}$ water and $0.05 \mathrm{ml}$ serum, respectively. (c) These curves illustrate the inhibition of the human acrosomal preparation by seminal plasma. The control cuvette contained $0.10 \mathrm{ml}$ acrosomal extract with $0.10 \mathrm{ml}$ water; the other cuvette contained $0.10 \mathrm{ml}$ acrosomal extract with $0 \cdot 10 \mathrm{ml}$ seminal plasma diluted $1: 4$. 
pH 8 (Text-fig. 2). This activity was inhibited by soybean trypsin inhibitor (Text-fig. 2a) and TLCK (Text-fig. 2b). The latter inhibition was most pronounced if the acrosome material and TLCK was mixed and allowed to stand for about $30 \mathrm{~min}$ before the spectrophotometric assay. Seminal plasma was also found to inhibit the enzymatic activity (Text-fig. 2c) even when diluted $1: 12$ with the washing solution. Here, too, a short incubation before carrying out the assay seemed to increase the inhibition. In addition, seminal plasma was found to inhibit pancreatic trypsin. Serum, which is known to contain an $\alpha_{1}$-antitrypsin (Jensen, 1970) was found to inhibit the acrosomal enzyme activity (Text-fig. 2) as well as pancreatic trypsin.

The presence in seminal plasma of a potent inhibitor of acrosomal trypsinlike enzyme made it desirable to attempt a quantitative expression of the activity. For five donors, it was found that in the assay system used (Text-fig. 2) $1 \mathrm{mg}$ of 'acrosome protein' metabolized 0.238 to $0.333 \mathrm{micromol} \mathrm{TAME} / \mathrm{min}$.

The appearance of the acrosome after spermatozoa were subjected to the washing procedure alone gave the impression that some material must be lost during this stage; this would be in accord with previous reports that hyaluronidase is easily lost from the cells during washing and cold treatment (Mann, 1964; Ackerman, 1970). The supernates were therefore assayed for trypsin-like activity but with negative results, probably due to excessive dilution.

The significance of the evaginations of dense acrosomal material in the cells most markedly damaged by washing is not clear. Some of the structural relationships are reminiscent of the acrosome reaction (Bedford, 1970).

\section{DISCUSSION}

The method described seems to remove acrosomal material from human spermatozoa fairly selectively. In nearly all the cells examined, the anterior segment was totally devoid of content and an equatorial segment could only be recognized in about $20 \%$ of the cells. In electron microscope preparations, the rest of the cell compared favourably with normal untreated cells, but a small portion of the spermatozoa did show signs of damage. Thus, the isolated material must contain some material extracted from other parts of the spermatozoa. Other cellular elements present in semen probably also make some contribution to the sample of 'acrosomal material'. However, the procedure described here seems to be the most selective yet devised for isolation of human sperm acrosomal contents.

In preliminary experiments with procedures previously employed by other investigators, the use of sonication appeared to damage the neck cytoplasm and mid-piece rather severely in addition to causing early disruption of the outer acrosomal membrane. The use of $\mathrm{NaOH}$ and Hyamine caused complete removal of the acrosome but with extensive extraction of all segments of the tail. There was also considerable extraction of nuclear material. Thus, there is reason to believe that these methods are more generally damaging and far less selective for isolation of the acrosomal contents.

The characteristics of the enzymatic activity in the acrosomal preparations, ability to digest BAEE and TAME and inhibition by soybean trypsin inhibitor 
and TLCK, clearly place it in the group of trypsins (Walsh, 1970). In accord with the findings of Stambaugh \& Buckley $(1970 \mathrm{~b})$, there is no indication from the present study that the enzyme is present in an inhibited state in ejaculated spermatozoa as has been claimed by Bhalla, Caster \& Williams (1970), Zaneveld \& Williams (1970) and Zaneveld et al. (1969, 1970). Zaneveld and his colleagues also found an inhibitor of the trypsin-like activity in seminal plasma. Their failure to demonstrate trypsin-like activity in acrosomal preparations from ejaculates may have been due to inadequate washing of the cells before assay. The present study does not exclude the possibility that the enzyme is in a partially inhibited state but the fact that the activity per $\mathrm{mg}$ protein is relatively constant seems to argue against this possibility.

The detection of trypsin-like activity in ejaculated human spermatozoa provides additional biochemical basis for the ingenious visual demonstration by Gaddum \& Blandau (1970) of the gelatin-digesting activity of ejaculated human spermatozoa. These authors found, however, that seminal plasma also digests gelatin, suggesting that proteases other than the trypsin-like acrosomal enzyme may be involved.

Based on the evidence presented by Srivastava et al. (1965) and Stambaugh \& Buckley (1968a, b, 1969), it is tempting to consider the trypsin-like enzyme as the zona-lysing component of spermatozoa. However, several points need further clarification before this can be accepted. Gwatkin (1964) failed to dissolve the zona pellucida of mouse eggs with trypsin. The available electron microscope evidence on the state of the acrosome during fertilization seems to indicate that when the spermatozoon penetrates the zona, it has already lost the anterior segment of its acrosome and retains only the inner membrane of this segment and the equatorial segment (Barros \& Franklin, 1968; Bedford, 1968; Bedford, 1970). The fate of the equatorial segment (Yanagimachi \& Noda, 1970a, b) and several other details (Zamboni, 1971) remain a matter of controversy. It has yet to be established whether trypsin-like activity or other enzymes capable of zona lysis reside in the inner acrosomal membrane and the equatorial segment. Using fluorescing soybean trypsin inhibitor, Stambaugh \& Buckley (1970a) reported that the trypsin-like enzyme is bound to the inner acrosomal membrane. However, it is doubtful whether the resolution of this method is sufficient to answer this question.

It is evident that the trypsin-like activity and hyaluronidase activity are probably not the only enzymatic functions of the acrosome. Under the assay conditions used in this study, $1 \mathrm{mg}$ crystalline trypsin digested 247 micromol TAME/min (Walsh, 1970). By contrast, $1 \mathrm{mg}$ 'acrosomal protein' metabolized, on the average, $0.289 \mathrm{micromol}$ TAME/min or about $1 / 1000$ the activity of trypsin. Thus, there would seem to be much more protein in the acrosome than is involved in this particular enzymatic activity. Further studies are needed to determine the character of these other proteins, their possible enzymatic activity, their antigenic properties and their physiological rôle in normal reproduction.

\section{ACKNOWLEDGMENTS}

I am greatly indebted to Dr Henry Paulus, Department of Biological Chemistry, 
Harvard Medical School, for his invaluable assistance with the biochemical part of this work and for generously letting me use the technical facilities of his laboratory. The TLCK was kindly supplied by Dr F. Riordan, Department of Biological Chemistry, Harvard Medical School.

This work was supported by a Public Health Service International Postdoctoral Research Fellowship (number 1 FO5 TW 1681-01), by Contract 69-2107 from the Center for Population Studies, National Institute of Child Health and Human Development, and by Statens Laegevidenskabelige Forskningsraad and P. Carl Petersens Fond, Denmark.

\section{REFERENCES}

Ackerman, D. R. (1970) Hyaluronidase in human semen and sperm suspensions subjected to temperature shock and to freezing. F. Reprod. Fert. 23, 521.

Allison, A. G. \& Hartree, E. F. (1970) Lysosomal enzymes in the acrosome and their possible rôle in fertilization. 7. Reprod. Fert. 21, 501.

BarRos, C. \& FrankLin, L. E. (1968) Behaviour of the gamete membranes during sperm entry into the mammalian egg. 7. Cell Biol. 37, C13.

BEDFORD, J. M. (1968) Ultrastructural changes in the sperm head during fertilization in the rabbit. Am. 7. Anat. 123, 329.

BEDFoRd, J. M. (1970) Sperm capacitation and fertilization in mammals. Biol. Reprod. Suppl. 2, 128.

Bergmeyer, H.-U. (1963) Methods in enzymatic analysis. Academic Press, New York.

Bhalla, V. K., Caster, W. O. \& Williams, W. L. (1970) Gapacitation of sperm and inhibition of sperm enzymes. Fedn Proc. Fedn Am. Socs exp. Biol. 29, 644.

Clermont, Y., Clegg, R. E. \& Leblond, C. P. (1955) Presence of carbohydrates in the acrosome of the guinea pig spermatozoon. Expl Cell Res. 8, 453.

Flällarant, B. (1968) Sperm antibodies and sterility in men. Acta obstet. gynec. scand. Suppl. 4.

FrankLin, R. R. \& Dukes, C. D. (1964) Antispermatozoal antibody and unexplained infertility. Am. 7. Obstet. Gynec. 89, 6.

Gaddum, P. \& Blandau, R. J. (1970) Proteolytic reaction of mammalian spermatozoa on gelatin membranes. Science, N.Y. 170, 749.

Gwatkin, R. B. L. (1964) Effect of enzymes and acidity on the zona pellucida of the mouse egg before and after fertilization. 7. Reprod. Fert. 7, 99.

HARtree, E. F. \& SRIvastava, P. N. (1965) Chemical composition of the acrosome of ram spermatozoa. 7. Reprod. Fert. 9, 47.

Hathaway, R. R. \& HaRtReE, E. F. (1963) Observations on the mammalian acrosome: experimental removal of acrosomes from ram and bull spermatozoa. F. Reprod. Fert. 5, 225.

HJort, T. \& Hansen, K. B. (1971) Immunofluorescent studies on human spermatozoa. I. Detection of different spermatozoal antibodies and their occurrence in normal and infertile women. Clin. exp. Immunol. 8, 9.

Jensen, K. (1970) Alfa ${ }_{1}$-antitrypsin. Ugeskr. Lag. 132, 2167.

Lowry, O. H., Rosebrough, N. J., Farr, A. L. \& Randall, R. J. (1951) Protein measurement with the Folin phenol reagent. F. biol. Chem. 193, 265.

LufT, J. H. (1961) Improvements in epoxy resin embedding methods. F. biophys. biochem. Cytol. 9, 409.

ManN, T. (1964) The biochemistry of semen and of the male reproductive tract. Methuen, London.

Morton, B. E. (1968) A disruption and fractionation of bovine spermatozoa. F. Reprod. Fert. 15, 113.

Otani, Y., Ino, H., Inoue, S. \& Kagkami, T. (1971) Immunization of human female with human sperm and semen. Int. F. Fert. 16, 19.

Pedersen, H. (1969) Ultrastructure of the ejaculated human sperm. Z. Zellforsch. mikrosk. Anat. 94, 542.

Pedersen, H. (1970a) Ultrastructure of the ejaculated human sperm. In: Comparative Spermatology. Ed. B. Baccetti. Academic Press, New York.

Pedersen, H. (1970b) Observations on the axial filament complex of the human spermatozoon. $\mathcal{F}$. Ultrastruct. Res. 33, 451 .

Pedersen, H. (1972) Further observations on the fine structure of the human spermatozoon. $Z$. Zellforsch. Mikrosk. Anat. 123, 305.

Schwimmer, W. B., Ustay, K. A. \& Behrman, S. J. (1967) Sperm agglutinating antibodies and decreased fertility in prostitutes. Obstet. Gynec., N.Y. 30, 192.

Srivastava, P. N., Adams, C. E. \& Hartree, E. F. (1965) Enzymatic action of acrosomal preparations on the rabbit ovum in vitro. 7 . Reprod. Fert. 10,61. 
Srivastava, P. N., Zaneveld, L. J. D. \& Williams, W. L. (1970) Mammalian sperm acrosomal neuraminidases. Biochem. biophys. Res. Commun. 39, 575.

Stambavgh, R. \& Buckley, J. (1968a) Zona pellucida dissolution enzymes of rabbit sperm head. Science, $\mathcal{N}$. Y. 161, 585.

Stambaugh, R. \& BuckLEy, J. (1968b) Identification of the zona pellucida penetration enzymes of the rabbit sperm acrosomes. Int. Congr. Anim. Reprod. Artif. Insem., Paris, p. 635.

Stambaugh, R. \& BuckLey, J. (1969) Identification and subcellular localization of the enzymes effecting penetration of the zona pellucida by rabbit spermatozoa. F. Reprod. Fert. 19, 423.

Stambaugh, R. \& Buckley, J. (1970a) Subcellular localization of spermatozoal trypsin-like enzymatic activity by fluorescence microscopy. Proc. Soc. Study Reprod., Ohio.

Stambaugh, R. \& Buckley, J. (1970b) Comparative studies of the acrosomal enzymes of rabbit, rhesus monkey, and human spermatozoa. Biol. Reprod. 3, 275.

Strauss, E. K. (1965) Sperm immobilization in the human vagina by induced muco-antibody. Fert. Steril. 16, 346.

Teichman, R. J. \& Bernstein, M. H. (1969) A morphological and biochemical comparison of rabbit, human, and bull acrosomes. F. Cell Biol. 43, 144a.

WALSH, K. A. (1970) Trypsinogens and trypsins of various species. In: Methods in Enzymology. Eds. S. P. Colowick and N. O. Kaplan. Academic Press, New York.

YANAGIMACHI, R. \& NodA, Y. D. (1970a) Ultrastructural changes in the sperm head during fertilization. F. Ultrastruct. Res. 31, 465.

YANAGIMACHI, R. \& NoDA, Y. D. (1970b) Electron microscope studies of sperm incorporation into the golden hamster egg. Am. F. Anat. 128, 429.

ZambonI, L. (1971) Acrosome loss in fertilizing mammalian spermatozoa: a clarification. F. Ultrastruct. Res. 34, 401.

Zaneveld, L. J. D., SRivastava, P. N. \& Williams, W. L. (1969) Relationship of a trypsin-like enzyme in rabbit spermatozoa to capacitation. F. Reprod. Fert. $20,337$.

Zaneveld, L. J. D., SRivastava, P. N. \& Williams, W. L. (1970) Inhibition by seminal plasma of acrosomal enzymes in intact sperm. Proc. Soc. exp. Biol. Med. 133, 1172.

Zaneveld, L. J. D. \& Williams, W. L. (1970) A sperm enzyme that disperses the corona radiata and its inhibition by decapacitation factor. Biol. Reprod. 2, 363. 